\title{
Growth and risk at the industry level: The real effects of financial liberalization
}

\author{
Andrei A. Levchenko ${ }^{\mathrm{a}, \mathrm{b}, *}$, Romain Rancière ${ }^{\mathrm{b}, \mathrm{c}, \mathrm{d}}$, Mathias Thoenig ${ }^{\mathrm{c}, \mathrm{d}, \mathrm{e}}$ \\ a University of Michigan, USA \\ b IMF, USA \\ c PSE, France \\ d CEPR, United Kingdom \\ e Université de Genève, Switzerland
}

\section{A R T I C L E I N F O}

\section{Article history:}

Received 28 May 2007

Received in revised form 2 June 2008

Accepted 4 June 2008

\section{JEL classification}

F02

F21

F36

F4

Keywords:

Financial liberalization

Growth

Volatility

Industry-level data

Difference-in-differences estimation

Propensity score matching

\begin{abstract}
A B S T R A C T
This paper analyzes the effects of financial liberalization on growth and volatility at the industry level in a large sample of countries. We estimate the impact of liberalization on production, employment, firm entry, capital accumulation, and productivity. In order to overcome omitted variables concerns, we employ a number of alternative difference-in-differences estimation strategies. We implement a propensity score matching algorithm to find a control group for each liberalizing country. In addition, we exploit variation in industry characteristics to obtain an alternative set of difference-in-differences estimates. Financial liberalization is found to have a positive effect on both growth and volatility of production across industries. The positive growth effect comes from increased entry of firms, higher capital accumulation, and an expansion in total employment. By contrast, we do not detect any effect of financial liberalization on measured productivity. Finally, the growth effects of liberalization appear temporary rather than permanent.
\end{abstract} (c) 2008 Elsevier B.V. All rights reserved.

\section{Introduction}

Financial markets have been liberalized dramatically in many countries over the past three decades. Fig. 1 depicts recent trends in the indicators of financial openness. Most de jure measures of restrictions on domestic capital allocation or international capital flows show a strong trend towards liberalization. Indeed, capital flows across borders have correspondingly grown at a higher pace than the expansion of goods trade, and much faster than GDP. What are the effects of financial liberalization? In spite of a theoretical case that financial liberalization should improve the allocation of capital and increase growth, the growth effects of financial liberalization have not been easy to demonstrate in cross-country data. At the same time, worries persist that financial liberalization may result in higher volatility. ${ }^{1}$

\footnotetext{
* Corresponding author. International Monetary Fund, 700 19th Street NW Washington, DC, 20431, USA

E-mail addresses: alev@umich.edu (A.A. Levchenko), rranciere@imf.org (R. Rancière), thoenig@ecopo.unige.ch (M. Thoenig).

${ }^{1}$ Kose et al. (2006) provide a comprehensive exposition of basic facts about the current wave of financial globalization, and review existing literature on its growth and volatility effects.
}

This paper examines the relationship between financial liberalization, growth, and volatility using a large industry-level panel dataset. The empirical analysis answers three sets of questions. First, what is the impact of financial liberalization on output growth and volatility at the industry level? Both growth and volatility effects have been analyzed separately in cross-country data. However, to obtain a reliable estimate of the their relative importance it is essential to consider these effects within a unified empirical framework. Second, what are the channels through which financial liberalization affects growth? And third, are the effects of financial liberalization permanent or temporary? The answers to the last two questions shed light on the nature of the relationship between liberalization and growth, and can help distinguish between the different theoretical possibilities.

The main findings can be summarized as follows. Financial liberalization increases both growth and volatility of output. These effects are robust to a variety of specifications and estimation strategies. The growth effect is driven by higher employment, greater capital accumulation, and greater firm entry. By contrast, we do not detect any impact of liberalization on TFP growth. Finally, the growth impact is temporary rather than permanent: for output, firm entry, and employment, the effect decreases in magnitude over time, and 


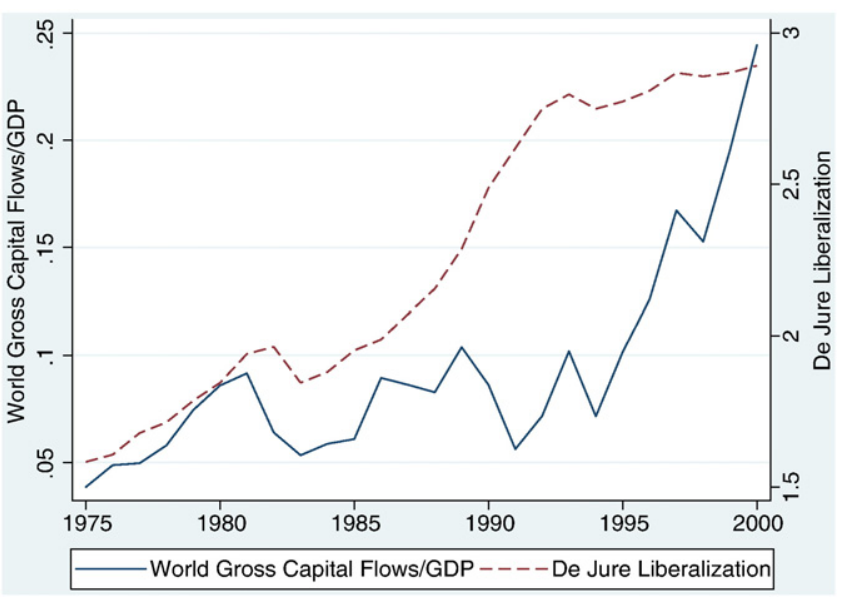

Fig. 1. Worldwide financial liberalization trends. The world gross capital flows/GDP are the sum of the gross capital flows across countries, divided by world GDP, in each year. Source: IMF Balance of Payments Statistics and World Bank's World Development Indicators. De jure liberalization is the average composite index of financial liberalization across countries in each year. The index ranges from 1 (least liberalized) to 3 (fully liberalized). Source: Kaminsky and Schmukler, (2008).

becomes insignificant after 6 years, while the impact on capital accumulation is slightly more long-lasting. The only persistent effect is on competition: the impact of financial liberalization on the price-cost margin - a measure of markups - increases progressively for the first few post-liberalization years, and remains significantly negative throughout the period we analyze. We conclude that financial liberalization has a permanent effect on the level of output, but no persistent effect on output growth. While the effect of financial liberalization on volatility is also most pronounced on impact, we cannot rule out the possibility of a permanent increase in the variance of output growth.

When it comes to interpreting these results, it is useful to consider the range of theoretical possibilities for the growth benefits associated with financial liberalization. At one extreme, in a standard deterministic neoclassical framework, capital mobility accelerates convergence but has no long-run effect on growth or the level of income. ${ }^{2}$ At the other extreme, in an endogenous growth framework riskdiversification and specialization in more efficient technologies can have permanent growth-enhancing effects. ${ }^{3}$ Our findings of a permanent level effect but no persistent growth effect seem to reject either of these two polar views. However, they are consistent with the notion that capital mobility raises production efficiency by reducing domestic distortions. ${ }^{4}$ In particular, our empirical results can be rationalized within a neoclassical model with imperfect competition. In such a model, a permanent reduction in markups leads to a temporary growth increase reflecting convergence towards higher levels of capital and income. ${ }^{5}$

Until recently, most of the empirical literature studying financial liberalization used country-level data, and as a result was subject to both conceptual and econometric problems. First, conceptually, if financial markets are not perfect within the country, the economy

\footnotetext{
2 See Barro et al. (1995), and Gourinchas and Jeanne (2006).

3 See Saint-Paul (1992) and Obstfeld (1994).

4 See Tornell and Velasco (1992) and Ouadrini (2005) for models in which capital mobility reduces production inefficiencies associated with imperfect property rights or time-inconsistent fiscal policies. In contrast, Tressel and Verdier (2007) suggest that financial liberalization can increase production inefficiencies by exacerbating the misallocation of credit towards politically connected firms.

${ }^{5}$ See Galí $(1994,1995)$ for a detailed analysis. Note that in this model, output growth volatility tends to increase temporarily as an economy transitions from a steady-state with a low level of capital and high markups to a steady-state with high level of capital and low markups.
}

does not behave like a representative agent. Indeed, there is strong evidence that risk sharing between agents within a country is far from complete even in the most advanced economies like the U.S. (Attanasio and Davis, 1996; Hayashi et al., 1996). For developing countries as well, there is a large amount of evidence, surveyed in Banerjee and Duflo (2005), that the representative agent assumption is strongly violated. When that is the case, analyzing aggregate data may in some cases lead us to miss the most important effects of financial liberalization, and in others produce estimates that are not informative about welfare implications for the average individual in the economy (Levchenko, 2005; Broner and Ventura, 2006). The use of sector-level data therefore enables us to get a deeper understanding of how financial liberalization affects the typical agent. In the last section of the paper, we demonstrate the importance of the distinction between industry-level and aggregate effects. In particular, while the change in aggregate growth implied by our estimates is the same as the industry-level change, aggregate volatility increases by much less than sector-level volatility due to diversification across sectors.

Second, existing cross-country results are most likely subject to significant endogeneity and omitted variables problems. The key feature of our empirical approach is the variety of empirical strategies we pursue in order to obtain reliable estimates. We isolate a number of financial liberalization episodes using the de jure liberalization indices developed by Kaminsky and Schmukler (2008) and compare the growth and volatility of outcomes, such as output and employment, during the 10 years immediately before and after the liberalization date. To address the omitted variables problem, the paper employs two difference-in-differences strategies. The first, more novel to this paper, uses as the control group countries that did not liberalize in the same period. To overcome a selection on observables problem that could arise in such an exercise, we develop a propensity score matching procedure to select a suitable control group for each liberalizing country. The second approach, a more conventional one, exploits differences in sector characteristics in the spirit of Rajan and Zingales (1998) to identify a causal link between liberalization and growth and volatility. As a way to assess the robustness of our results, we also estimate the relationship between de facto measures of financial liberalization, such as those used by Kose et al. (2003) and Lane and Milesi-Ferretti (2006) and growth and volatility. In spite of important differences in the independent variables and specifications, the findings are remarkably similar for the two types of measures. ${ }^{6}$

This paper is related to the large literature on the growth and volatility effects of financial liberalization, surveyed comprehensively by Kose et al. (2006) and Henry (2007). Here, we focus on the papers most closely related to ours. While most existing studies in this literature use cross-country data, Galindo et al. (2002), and Gupta and Yuan (2006) employ industry-level data and the Rajan and Zingales (1998) methodology to analyze the effects of financial liberalization on growth. Our paper differs from these two contributions in several important respects. First, we investigate the volatility effects of financial liberalization, doing so within the same empirical framework as the growth effects. This produces a more complete picture of the effects of financial liberalization, and enables us to evaluate its overall impact. Second, while the Rajan-Zingales methodology makes it possible to identify the differential impact of financial liberalization across industries, it does not allow one to estimate the overall effect of financial liberalization. This approach is thus of limited usefulness

\footnotetext{
${ }^{6}$ The advantage of de jure measures is that they reflect policy levers, and thus results based on them may have clearer policy implications for reforms that a government might consider. Their disadvantage is that they may capture quite poorly the actual degree of financial integration, either because the true nature of legal restrictions is mismeasured, or because these restrictions are imperfectly enforced. Nonetheless, we place more weight on the de jure measures, since the de facto ones represent equilibrium outcomes, and may be more noisy reflections of policy.
} 
when it comes to policy evaluation of financial liberalization reforms. By contrast, our paper proposes a methodology to measure the overall effect. Third, we establish whether or not the effects of financial liberalization are temporary or permanent. And finally, we use both de jure and de facto measures of financial liberalization to assess robustness of the results. In particular, de facto measures have not previously been used in industry-level analysis. ${ }^{7}$

The rest of the paper is organized as follows. Section 2 describes the data. Section 3 lays out the empirical methodology and presents the estimating equations. Section 4 presents the results, and discusses the implications of our sector-level estimates for aggregate growth and volatility. Section 5 concludes.

\section{Data}

Industry-level production, employment, investment, and the number of establishments come from the 2006 UNIDO Industrial Statistics Database (United Nations Industrial Development Organization, 2006). This paper uses the version that reports data according to the 3-digit ISIC Revision 2 classification for the period 1963-2003 in the best cases. There are 28 manufacturing sectors, plus the information on total manufacturing. We use data reported in current U.S. dollars, and convert them into constant international dollars using the Penn World Tables (Heston et al., 2002). ${ }^{8}$ The resulting dataset is an unbalanced panel of 56 countries, but we ensure that for each country-year we have a minimum of 10 sectors, and that for each country, there are at least 10 years of data.

The data on de jure financial liberalization come from Kaminsky and Schmukler (2008) (henceforth KS), who provide indices of liberalization in the stock market, the banking system, and freedom of international transactions for 28 countries. Along each of the three dimensions of liberalization, KS assign a value of 1,2 , or 3 for each country and year, with 3 indicating the most liberalized. They also provide a composite index, which is a mean of the three subcomponents. As a measure of de facto financial liberalization we use the gross capital flows as a share of GDP. The gross capital flows are the sum of gross inflows and gross outflows, obtained from the IMF's Balance of Payments Statistics. This measure, which is parallel to the aggregate trade openness (exports plus imports), has been used by Kose, Prasad, and Terrones (2003), as well as several subsequent papers. ${ }^{9}$

In order to test for the differential effect of financial liberalization across industries, we employ the dependence on external finance measure introduced by Rajan and Zingales (1998). The Rajan and Zingales measure is defined as capital expenditure minus cash flow, divided by capital expenditure, and is constructed based on U.S. firmlevel data. Intuitively, it is intended to capture the share of investment that must be financed with funds external to the firm. ${ }^{10}$ We also make use of the industry-level measure of liquidity needs compiled by

\footnotetext{
${ }^{7}$ A small number of studies attempt to measure the effect of financial liberalization by using firm-level data for several countries. Henry (2000a,b) finds that stock market liberalizations are associated with a reduction in the cost of capital, followed by an investment boom in a sample of listed firms in 12 emerging markets. Also using listed firms, Mitton (2006) finds that firms with stocks that are open to foreign investors experience higher growth, greater profitability, and improved efficiency. Alfaro and Charlton (2007) use a large cross-section of both listed and non-listed firms in 1999 and 2004 to show that international financial integration fosters the entry of new firms, a finding in line with our industry-level results.

${ }^{8}$ Using the variable name conventions from the Penn World Tables, this deflation procedure involves multiplying the nominal U.S. dollar value by $(100 / P) *($ RGDPL/ CGDP) for output, and $(100 / P)^{*}(\mathrm{KI} / \mathrm{CI})^{*}(\mathrm{RGDPL} / \mathrm{CGDP})$ for investment to obtain the deflated value.

${ }^{9}$ We check the results by using instead a measure of stocks of gross foreign assets and liabilities from Lane and Milesi-Ferretti (2006). The results are robust to this alternative index of de facto liberalization, and we do not report them to avoid unnecessary repetition.

${ }^{10}$ We use the version of the variable assembled by Klingebiel, Kroszner, and Laeven (2007), in which industries are classified according to the 3-digit ISIC Revision 2 classification.
}

Raddatz (2006), defined as inventories as a share of sales. A sector has a higher need for liquidity when a smaller fraction of inventory accumulation can be financed by ongoing cash flow. Additional controls include financial development - private credit as a share of GDP - sourced from Beck et al. (2000), and trade openness at the industry level constructed by di Giovanni and Levchenko (in press).

Appendix Table A1 lists the countries in the sample and the summary statistics for growth, volatility, and gross capital flows for each country, as well as the means and standard deviations for the entire sample. Table A5 in the supplementary web appendix lists the sectors used in the analysis, along with the values of external finance dependence and liquidity needs.

\section{Empirical methodology}

\subsection{Baseline specification}

In the baseline approach to estimating the effects of financial liberalization, we date the liberalization events in a sample of countries, and then compare outcomes before and after liberalization. This strategy relies on the de jure indicators compiled by KS to identify the liberalization episodes. Because we require precise liberalization dates, we must set a threshold for the KS index, above which the country is considered liberalized, and below which it is not. ${ }^{11}$ The resulting set of liberalization dates is listed in Appendix Table A2.

To estimate the effects of financial liberalization on economic outcomes, we use a conventional difference-in-differences model. For each liberalization episode, we compute the outcome variable, as well as the relevant controls, for the 10 -year period before, and the 10 -year period after the liberalization date. Then, for each episode, we identify a control group of countries from among those that did not liberalize during the 20-year period around the liberalization date. Using these, we estimate the following set of specifications:

$$
\begin{aligned}
& \text { VOLATILITY }_{i c t}=\beta_{0} \text { POST }_{t}+\beta_{1} \text { TREATED }_{c t}+\gamma X_{i c t}+\Delta+\varepsilon_{i c t} \\
& \text { GROWTH }_{i c t}=\beta_{0} \text { POST }_{t}+\beta_{1} \text { TREATED }_{c t}+\gamma X_{i c t}+\Delta+\varepsilon_{i c t}
\end{aligned}
$$

Here and throughout the paper, $c$ indexes countries, $i$ industries, and $t$ time periods. On the left-hand side is either the 10-year average growth rate of a variable $\left(\mathrm{GROWTH}_{i c t}\right)$, or the standard deviation of that growth rate calculated over the 10 year span (VOLATILITY ${ }_{i c t}$ ). Model (1) is the "classic" difference-in-differences specification. The left-hand side variable is measured in two periods, before and after treatment. Thus, by construction, in this model $t$ takes on only two values: before liberalization, and after it. The variable $\mathrm{POST}_{t}$ takes on the value of 0 before the liberalization episode, and 1 after. It is common to both treated and control observations. Finally, the coefficient of interest $\beta_{1}$ is on the variable TREATED $D_{c t}$, which is a binary indicator for whether a country is liberalized in a given period. Intuitively, while the familiar Rajan-Zingales-type model uses nonfinancially intensive sectors as a control group for the financially intensive sectors, this empirical strategy uses non-liberalizing countries as a control group for the liberalizing country.

The vector of controls $X_{i c t}$ contains the beginning-of-period share of the sector in total output, as well as exports and imports as a share of output in the sector. ${ }^{12}$ In addition, $X_{i c t}$ includes a measure of

\footnotetext{
11 Whenever the financial liberalization index used is not binary, an important question is how to define a financial liberalization event. In the baseline regressions we classify a country as liberalized whenever all three components of the index domestic, capital account, and stock market - indicate full liberalization. This approach emphasizes the complementarities between the different financial liberalization reforms.

${ }^{12}$ We use beginning-of-period values rather than period averages for share to avoid inducing a mechanical correlation with the left-hand side variable: a faster-growing sector will tend to have higher share in the contemporaneous period.
} 
financial development (private credit as a share of GDP), and the interaction between the country's financial development and the RajanZingales measure of dependence on external finance. These are meant to control for the well-documented differential growth effects of financial development. Raddatz (2006) finds that volatility in a sector responds to financial development differentially depending on its liquidity needs. In the volatility specifications we thus control for this effect, by including instead the interaction between financial development and liquidity needs. Appendix Table A3 presents the correlation matrix for the independent variables. Both specifications include a set of fixed effects $\Delta$. The ability to employ a variety of fixed effects is a major strength of our empirical approach, as these can potentially control for a wide range of omitted variables. The use of fixed effects becomes especially powerful in a three-dimensional panel, which makes it possible to use interacted effects, such as country $\times$ sector, or sector $\times$ time.

The key question is what countries to assign to the control group for each liberalization episode. This paper pursues two strategies. First, for each episode we use as the control group all of the countries that did not liberalize around the same time as the liberalizing country. This procedure can result in a large number of heterogeneous countries constituting each control group. To refine this procedure one step, we only use OECD countries as available controls for the OECD liberalizers, and non-OECD countries as possible controls for the non-OECD liberalizers. The advantage of this approach is that it uses a large amount of information for what is happening in various non-liberalizing countries around the time of each liberalization episode. The disadvantage is that besides the coarse $\mathrm{OECD} /$ non-OECD refinement, no attempt is made to use country characteristics in picking the control groups. Potentially, this can result in the control group countries having very different characteristics from the treated ones for each episode. Note that the large size of the control groups should help in this respect, since the country heterogeneity would be averaged out among the large number of control countries. Also, many of the obvious differences, such as the overall level of development, which can arise between a treated country and its control, would be accounted for by the country fixed effects included in the estimation.

Nonetheless, potential selection concerns remain. In order to overcome them, we also employ a propensity score matching procedure (henceforth PSM) to find a suitable control group. The supplementary web appendix to this paper describes it in detail. The PSM procedure seeks to use information on observable characteristics of subjects to estimate a probability model for being treated. Then, for each instance of a treated observation, it uses the information on the observables to identify a non-treated observation closest to the treated one. That non-treated observation then becomes the control group for the treated one. The first economic applications of the propensity score techniques are due to Dehejia and Wahba (1999, 2002), while in international economics they were first used by Persson (2001) and Glick, Guo and Hutchinson (2006). Though it has been applied widely in various empirical analyses, it must be kept in mind that the PSM method corrects only for selection on observables, not unobservables. Furthermore, it can be sensitive to the set of conditioning variables used to predict propensity scores (see Smith and Todd, 2005).

\subsection{Alternative estimation strategies}

Because the financial liberalization variable varies at the country $\times$ time level, in the baseline empirical model we cannot include country $\times$ time effects that would capture any other time-varying country characteristics not picked up by the controls. An alternative approach is to exploit sector-level characteristics in the spirit of Rajan and Zingales (1998) to identify a causal relationship between financial liberalization and outcomes. We rely on the variation in the dependence on external finance introduced by Rajan and Zingales (1998), as well as the liquidity needs measure from Raddatz (2006). In particular, we estimate the following specifications on the sample of liberalizing countries:

$$
\begin{aligned}
& \text { VOLATILITY }_{i c t}=\beta_{\text {CHAR }_{i}}{ }^{*} \text { TREATED }_{c t}+\gamma X_{i c t}+\delta_{c t}+\delta_{i}+\varepsilon_{i c t} \\
& \text { GROWTH }_{i c t}=\beta \text { CHAR }_{i}^{*} \text { TREATED }_{c t}+\gamma X_{i c t}+\delta_{c t}+\delta_{i}+\varepsilon_{i c t},
\end{aligned}
$$

where $c$ indexes countries, $i$ industries, and $t$ time periods. Same as above, GROWTH Grt $_{i c t}$ and VOLATILITY $i c t$ are the average growth rates over the 10-year period, and the standard deviation of the growth rate over the same period, respectively. TREATED ${ }_{c t}$ is defined identically to the above specification: it is zero except in the post-liberalization period for the country that liberalized. $\mathrm{CHAR}_{i}$ refers to the industry characteristic used in estimation. This characteristic is either the Rajan and Zingales measure of dependence on external finance, or the Raddatz measure of liquidity needs. $X_{i c t}$ is a vector of controls. All of the specifications include a full set of country $\times$ time effects $\delta_{c t}$, as well as sector effects $\delta_{i}$. Thus, in this model we identify the effect of financial liberalization purely from the differential effects across industries within a country. The Rajan and Zingales-type approach is a common one in the literature, indeed we are not the first to analyze the growth effects of financial liberalization with this strategy (though we are the first, to our knowledge, to address the issue of volatility).

It is important to emphasize the pros and cons of model (1) compared to (2). The disadvantage of the former is that it may suffer from an omitted variables problem, because of our inability to include country $\times$ time effects. Its main advantage is that it allows us to estimate the direct effect of financial liberalization on the average growth and volatility across sectors within a country. By contrast, the omitted variables problem is overcome in the Rajan-Zingales-type model. However, its key shortcoming is that because it relies solely on the within-country cross-industry variation, it does not allow the researcher to identify the magnitude of the overall effect. That is, the growth effect of financial liberalization - the object of much study using the cross-country regression approach - is subsumed in the country $\times$ time fixed effect.

To further check robustness of the results to alternative measures of financial liberalization, we estimate an empirical model based on de facto indices rather than de jure ones:

$$
\begin{aligned}
& \text { VOLATILITY }_{i c t}=\beta \text { FINOPEN }_{c t}+\gamma X_{i c t}+\Delta+\varepsilon_{i c t} \\
& \text { GROWTH }_{i c t}=\beta \text { FINOPEN }_{c t}+\gamma X_{i c t}+\Delta+\varepsilon_{i c t} .
\end{aligned}
$$

The sample is a non-overlapping panel of 10-year averages, 1970$79,1980-89,1990-99$, thus the subscript $t$ refers to decades. The variable of interest, FINOPEN Ft $_{c}$, is the gross capital flows as a share of GDP (see Kose et al. 2003). Finally, we also consider a Rajan-Zingalestype difference-in-differences panel specification in which the de facto measure of financial integration, FINOPEN $_{c t}$, is interacted with industry characteristics.

\section{Results}

\subsection{Volatility and growth}

We now discuss the results of estimating the baseline model (1). Table 1 reports the estimates of the relationship between financial liberalization and volatility of output. The first four columns use the full control group, while the last four use the PSM group. As we cannot use country $\times$ time effects, we experiment with various configurations of fixed effects to control for omitted variables. Column 1 presents estimation results with country fixed effects, while column 2 uses country $\times$ sector fixed effects. Column 3 uses country and group $\times$ time fixed effects, where we define a "group" to be a single liberalizing country plus all its control countries. The group $\times$ time effects control for the time variation in the variables affecting both the treated and the control countries, such as the changes in the global conditions. 
Table 1

Difference-in-differences results based on control countries, volatility.

\begin{tabular}{|c|c|c|c|c|c|c|c|c|}
\hline & (1) & $(2)$ & (3) & $(4)$ & $(5)$ & $(6)$ & (7) & $(8)$ \\
\hline \multicolumn{9}{|c|}{ Dep. var:: standard deviation of the growth rate of output } \\
\hline \multirow[t]{2}{*}{ Treated } & $0.022^{* *}$ & 0.021 & $0.015^{* *}$ & $0.022 * *$ & $0.022 * *$ & $0.022 * *$ & $0.024^{* * *}$ & $0.023 *$ \\
\hline & [0.009] & {$[0.014]$} & {$[0.006]$} & [0.009] & {$[0.011]$} & [0.011] & {$[0.006]$} & [0.013] \\
\hline \multirow[t]{2}{*}{ Post } & -0.002 & -0.001 & 0.013 & -0.001 & -0.005 & -0.004 & $0.034 * * *$ & -0.003 \\
\hline & [0.007] & {$[0.011]$} & {$[0.013]$} & [0.007] & {$[0.016]$} & {$[0.017]$} & {$[0.012]$} & {$[0.020]$} \\
\hline \multirow[t]{2}{*}{ Exports/output } & $0.030 * * *$ & 0.016 & $0.030 * * *$ & $0.016^{* * *}$ & $0.021^{* * *}$ & $0.016^{* *}$ & $0.021^{* * *}$ & 0.008 \\
\hline & [0.005] & [0.015] & [0.005] & [0.005] & {$[0.008]$} & [0.008] & [0.008] & [0.007] \\
\hline \multirow[t]{2}{*}{ Imports/output } & 0.003 & 0.000 & 0.002 & 0.001 & 0.003 & 0.002 & 0.003 & 0.002 \\
\hline & [0.002] & [0.002] & [0.002] & [0.001] & [0.002] & [0.001] & [0.002] & [0.002] \\
\hline \multirow[t]{2}{*}{ Initial share } & $-0.281^{* * *}$ & $-0.888^{* * *}$ & $-0.282^{* * *}$ & $-0.250^{* * *}$ & $-0.234^{* * *}$ & $-0.445^{*}$ & $-0.235^{* * *}$ & -0.103 \\
\hline & {$[0.026]$} & {$[0.216]$} & {$[0.026]$} & [0.059] & [0.047] & [0.259] & [0.047] & [0.092] \\
\hline \multirow{2}{*}{ Private credit } & -0.016 & $-0.124^{* *}$ & $-0.073^{* *}$ & $-0.069 *$ & 0 & -0.027 & -0.017 & -0.017 \\
\hline & [0.037] & {$[0.062]$} & {$[0.037]$} & {$[0.041]$} & [0.092] & [0.109] & {$[0.060]$} & [0.118] \\
\hline \multirow[t]{2}{*}{ Private credit* Liq. needs } & -0.089 & 0.617 & -0.088 & $0.258^{*}$ & -0.067 & 0.099 & -0.062 & 0.03 \\
\hline & [0.057] & [0.397] & [0.057] & [0.131] & {$[0.072]$} & [0.383] & {$[0.072]$} & [0.245] \\
\hline Country FE & Yes & No & Yes & Yes & Yes & No & Yes & Yes \\
\hline Country*Sector FE & No & Yes & No & No & No & Yes & No & No \\
\hline Group*Time FE & No & No & Yes & No & No & No & Yes & No \\
\hline Group*Sector FE & No & No & No & Yes & No & No & No & Yes \\
\hline Control group & All & All & All & All & PSM & PSM & PSM & PSM \\
\hline Observations & 3789 & 3789 & 3789 & 3789 & 1738 & 1738 & 1738 & 1738 \\
\hline$R$-squared & 0.28 & 0.71 & 0.29 & 0.48 & 0.3 & 0.72 & 0.33 & 0.57 \\
\hline
\end{tabular}

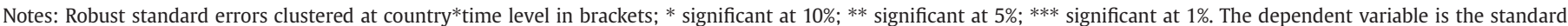

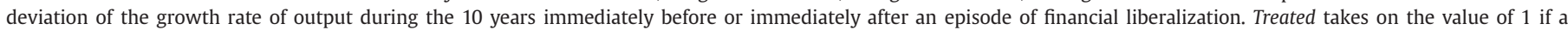

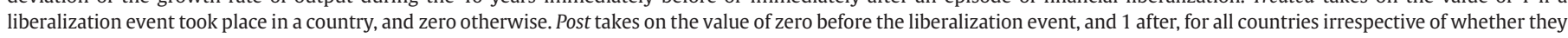

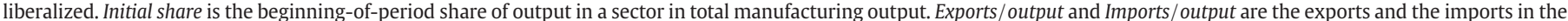

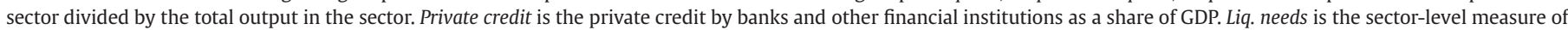

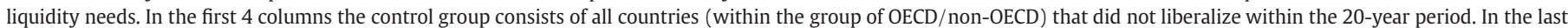


specified in the table. Variable definitions and sources are described in detail in the text.

Finally, column 4 uses the country and group $\times$ sector fixed effects. The latter is the same as using sector fixed effects, but within each individual group (as, for example, the sector effects may change over time). Because financial liberalization occurs at country $\times$ time level, we cluster the standard errors at country $\times$ time level as well, in order to avoid biasing the standard errors downwards.

Financial liberalization appears to increase volatility, as the coefficients of interest with both the full and the PSM control groups are positive and significant in all but one case. The coefficient is stable across the control groups and fixed effects configurations. It implies that a financial liberalization event is associated with a rise in the standard deviation of sectoral growth of 1.5-2.4 percentage points, or about $0.13-0.21$ standard deviations of volatility found in the sample.

Table 2 reports the results of estimating Eq. (1b), with the average growth rate of output over the 10-year period as the dependent variable. Once again, the first four columns use all available countries as control groups, while the last four report the results with the PSM control group. The columns differ in their use of fixed effects, identically to the estimates of the volatility effect of financial liberalization in Table 1.

We can see that financial liberalization has a robust positive effect on growth of output across sectors. This effect is present across all configurations of fixed effects except one. Using the PSM control group, the coefficient is significant at $1 \%$ in all cases. The magnitude of the effect is large. A financial liberalization, captured by moving the TREATED variable from 0 to 1 , is associated with a sector-level growth rate that is between 1.5 (full control group) and 3.5 (PSM control group) percentage points higher. This is equivalent to 0.17 and 0.40 of a standard deviation of the 10-year average sector-level growth rate observed in the sample.

Among the other controls, the most significant one is the initial share in total output, which has a negative sign in both the volatility and growth specifications. We interpret this as a standard convergence effect: sectors that are already large and established experience less growth in the subsequent period. Trade openness and financial development on its own do not appear to be robustly significant. The Rajan-Zingales term - private credit interacted with external finance dependence - has a significant impact on growth in most specifications, as has been extensively documented. By contrast, the interaction between financial development and the Raddatz measure of liquidity needs does not appear to have a robust impact on volatility in our sample.

We next discuss the results of the two alternative estimation strategies laid out above. First, we employ an alternative difference-indifferences model based on sector characteristics, models (2a) and (2b). Results are presented in Table 3. We can see that within countries, sectors that rely more on external finance tend to grow faster. In addition, sectors that rely on external finance, as well as sectors with greater liquidity needs tend to become more volatile as a result of financial liberalization.

The second alternative strategy, model (3), uses de facto measures of financial liberalization instead of de jure ones. Table 4 reports the results of estimating Eq. (3a), in which the dependent variable is the standard deviation of the growth rate of output over the 10 -year period, while Table 5 reports the results of estimating the impact of financial liberalization on growth, Eq. (3b). Unless otherwise indicated, we use the same specifications, controls, and configurations of fixed effects throughout for maximum comparability. The independent variable of interest, FINOPEN, is the average gross capital flows over the same 10year period. Because FINOPEN is measured at country $\times$ time level, we cluster the standard errors at the country $\times$ time level as well. The first four columns add progressively more fixed effects. ${ }^{13}$

FINOPEN has a positive effect on volatility for all configurations of fixed effects, though the level of significance is at $10 \%$ in most specifications. The magnitude of the impact of FINOPEN on volatility is

\footnotetext{
13 Column 1 includes country, sector, and time effects separately. Column 2 uses instead country and sector $\times$ time fixed effects. Column 3 adds country $\times$ sector and time effects. Note that in this column, identification comes purely from the time series variation in the variables of interest. Column 4 includes country $\times$ sector and sector $\times$ time fixed effects. This is the most stringent possible array of fixed effects (in terms of remaining degrees of freedom) that can be included in this specification. The only difference between the volatility and the growth specifications is that Eq. (3a) interacts private credit with the Raddatz measure of liquidity needs, while Eq. (3b) interacts private credit with the Rajan and Zingales measure of external finance dependence instead. This difference in the control variables does not affect the results.
} 
Table 2

Difference-in-difference results based on control countries, growth.

\begin{tabular}{|c|c|c|c|c|c|c|c|c|}
\hline & $(1)$ & (2) & (3) & $(4)$ & (5) & (6) & (7) & (8) \\
\hline \multicolumn{9}{|c|}{ Dep. var.: growth rate of output } \\
\hline \multirow[t]{2}{*}{ Treated } & $0.015^{*}$ & 0.151 & $0.015^{* *}$ & $0.016^{* * *}$ & $0.034^{* * *}$ & $0.035^{* * *}$ & $0.025^{* * *}$ & $0.035^{* * *}$ \\
\hline & {$[0.008]$} & {$[0.013]$} & {$[0.006]$} & [0.009] & {$[0.008]$} & [0.013] & {$[0.006]$} & {$[0.0010]$} \\
\hline \multirow[t]{2}{*}{ Post } & $-0.012^{* * *}$ & $-0.011^{*}$ & -0.003 & $-0.013^{* * *}$ & $-0.021 * * *$ & $-0.021^{*}$ & $-0.007^{*}$ & $-0.021 * *$ \\
\hline & {$[0.004]$} & {$[0.006]$} & {$[0.002]$} & {$[0.004]$} & {$[0.007]$} & {$[0.011]$} & {$[0.004]$} & {$[0.009]$} \\
\hline \multirow[t]{2}{*}{ Exports/output } & -0.004 & $-0.013^{* *}$ & -0.004 & -0.004 & 0.003 & -0.004 & 0.003 & 0.004 \\
\hline & {$[0.004]$} & {$[0.006]$} & {$[0.004]$} & {$[0.003]$} & [0.005] & [0.013] & [0.005] & $0.006]$ \\
\hline \multirow[t]{2}{*}{ Imports/output } & 0 & -0.001 & 0 & 0 & $-0.004^{*}$ & -0.003 & -0.005 & $-0.005^{*}$ \\
\hline & {$[0.000]$} & {$[0.002]$} & [0.001] & {$[0.001]$} & {$[0 . .002]$} & {$[0.003]$} & {$[0.002]$} & {$[0.033]$} \\
\hline \multirow[t]{2}{*}{ Initial share } & $0.053 * * *$ & $1.553^{* * *}$ & $0.054 * * *$ & $0.218^{* * *}$ & -0.036 & -1.598 & -0.038 & -0.191 \\
\hline & [0.019] & {$[0.146]$} & {$[0.019]$} & {$[0.041]$} & {$[0.030]$} & {$[0.205]$} & {$[0.030]$} & {$[0.072]$} \\
\hline \multirow{2}{*}{ Private credit } & 0.026 & -0.006 & $-0.028^{*}$ & $0.039 *$ & 0.051 & -0.091 & 0.011 & 0.055 \\
\hline & {$[0.018]$} & [0.029] & {$[0.017]$} & {$[0.020]$} & [0.039] & {$[0.058]$} & {$[0.034]$} & [0.049] \\
\hline \multirow[t]{2}{*}{ Private credit* Extern. fin } & $0.053^{* * *}$ & $0.176^{* * *}$ & $0.052^{* * *}$ & 0.007 & $0.059 * * *$ & $0.182^{* * *}$ & $0.059 * * *$ & $0.053^{* *}$ \\
\hline & {$[0.005]$} & {$[0.016]$} & {$[0.005]$} & {$[0.016]$} & {$[0.007]$} & {$[0.027]$} & {$[0.007]$} & {$[0.026]$} \\
\hline Country FE & Yes & No & Yes & Yes & Yes & No & Yes & Yes \\
\hline Country* sector FE & No & Yes & No & No & No & Yes & No & No \\
\hline Group*time FE & No & No & Yes & No & No & No & Yes & No \\
\hline Group*sector FE & No & No & No & Yes & No & No & No & Yes \\
\hline Control group & All & All & All & All & PSM & PSM & PSM & PSM \\
\hline Observations & 3799 & 3799 & 3799 & 3799 & 1738 & 1738 & 1738 & 1738 \\
\hline$R$-squared & 0.35 & 0.75 & 0.39 & 0.5 & 0.43 & 0.79 & 0.47 & 0.63 \\
\hline
\end{tabular}

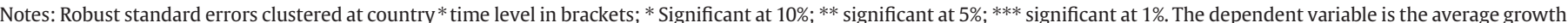

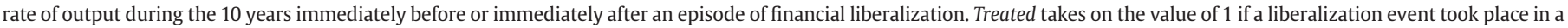

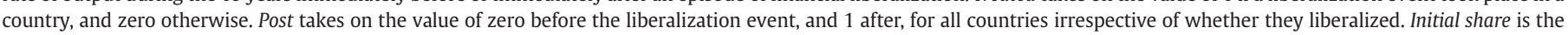

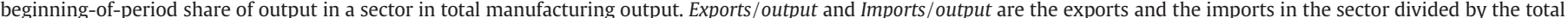

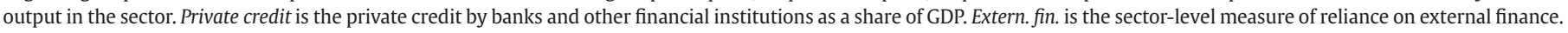

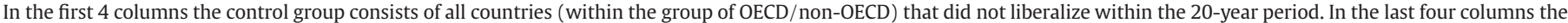

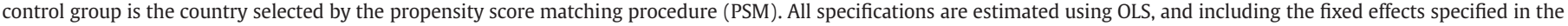
table. Variable definitions and sources are described in detail in the text.

economically significant. A one standard deviation change in FINOPEN is associated with a rise in the standard deviation of sector-level growth rate of 1.6 percentage points, equivalent to a movement of 0.13 standard deviations of the sectoral volatility in the sample. From Table 5, it is evident that the financial openness variable also has a positive effect on the growth rate of total output. The magnitude of the coefficient of interest is economically significant. A one standard deviation change in de facto financial openness is associated with a 1.3 percentage points increase in the output growth rate, a change of 0.16 standard deviations.

Finally, columns 5 and 6 of Tables 4 and 5 interact FINOPEN with the Rajan and Zingales measure of dependence on external finance and the Raddatz measure of liquidity needs. We include country $\times$ time fixed effects, controlling for other changes - such as reforms - that occur at country level and differ across time. Note that this makes it impossible to estimate the effect of FINOPEN on volatility or growth, but enables us to make a statement about its differential impact across sectors. Higher levels of FINOPEN increase volatility more in sectors that depend more on external finance, or with higher liquidity needs. When it comes to growth effects, it does appear to be the case that more financially dependent sectors grow faster as a result of liberalization than less financially dependent sectors. We do not find a significant differential growth effect for sectors with higher liquidity needs.

In sum, the estimates using the de jure and de facto measures financial integration yield strikingly similar results. Both reveal that financial liberalization increases both growth and volatility. Both effects are magnified in sectors that are more dependent of external finance, suggesting that those sectors are growing faster in part thanks to higher leverage in the post-liberalization period. ${ }^{14}$ When it comes

\footnotetext{
${ }^{14}$ How do our volatility results compare to the existing estimates? The literature using cross-country data has focused on the volatility of aggregate consumption rather than output. Even for aggregate consumption, the results are inconclusive: while Kose et al. (2003) find, paradoxically, that financial integration increases consumption volatility, Bekaert et al. (2006) find the opposite. Glick et al. (2006) demonstrate that financial integration reduces the likelihood of currency crises. However, these results are not directly comparable to ours, as currency crises are a different object than the year-on-year volatility studied here.
}

to magnitudes, the impact of a de jure liberalization on both growth and volatility is larger than that of increasing de facto capital flows by one standard deviation. The two measures of financial liberalization

Table 3

Difference-in-differences results based on industry characters.

\begin{tabular}{|c|c|c|c|c|}
\hline & (1) & $(2)$ & (3) & (4) \\
\hline & \multicolumn{4}{|l|}{ Output } \\
\hline & Growth & & Volatility & \\
\hline Extern. fin*Treated & $\begin{array}{l}0.016^{*} \\
{[0.010]}\end{array}$ & & $\begin{array}{l}0.024^{*} \\
{[0.015]}\end{array}$ & \\
\hline Liq. needs* Treated & & $\begin{array}{l}0.100 \\
{[0.067]}\end{array}$ & & $\begin{array}{l}0.158^{*} \\
{[0.097]}\end{array}$ \\
\hline Exports/output & $\begin{array}{l}0.004 \\
{[0.005]}\end{array}$ & $\begin{array}{l}0.005 \\
{[0.005]}\end{array}$ & $\begin{array}{l}0.007 \\
{[0.011]}\end{array}$ & $\begin{array}{l}0.008 \\
{[0.011]}\end{array}$ \\
\hline Imports/output & $\begin{array}{l}-0.004^{* *} \\
{[0.002]}\end{array}$ & $\begin{array}{l}-0.004^{* *} \\
{[0.002]}\end{array}$ & $\begin{array}{l}-0.001 \\
{[0.001]}\end{array}$ & $\begin{array}{l}-0.001 \\
{[0.001]}\end{array}$ \\
\hline Initial share & $\begin{array}{l}-0.109 * \\
{[0.066]}\end{array}$ & $\begin{array}{l}-0.113^{*} \\
{[0.064]}\end{array}$ & $\begin{array}{l}-0.332^{* * *} \\
{[0.105]}\end{array}$ & $\begin{array}{l}-0.329^{* * *} \\
{[0.103]}\end{array}$ \\
\hline Private credit*Extern. fin & $\begin{array}{l}0.005 \\
{[0.020]}\end{array}$ & & $\begin{array}{l}0.031 \\
{[0.029]}\end{array}$ & \\
\hline Private credit* Liq. needs & & $\begin{array}{l}0.237 \\
{[0.152]}\end{array}$ & & $\begin{array}{l}0.316 \\
{[0.202]}\end{array}$ \\
\hline Country* Time FE & Yes & Yes & Yes & Yes \\
\hline Sector FE & yes & yes & yes & yes \\
\hline Observations & 852 & 852 & 851 & 851 \\
\hline$R$-squared & 0.55 & 0.55 & 0.46 & 0.46 \\
\hline
\end{tabular}

Notes: Robust standard errors in brackets; * significant at $10 \%$; ** significant at $5 \%$; $* * *$ significant at $1 \%$. The dependent variable is the average growth rate, or the standard deviation of the growth rate of output during the 10 years immediately before or immediately after an episode of financial liberalization. Treated takes on the value of 1 if a liberalization event took place, and zero otherwise. Private credit is the private credit by banks and other financial institutions as a share of GDP. Extern. fin. is the sector-level measure of reliance on external finance. Liq. needs is the sector-level measure of liquidity needs. Initial share is the beginning-of-period share of output in a sector in total manufacturing output. Exports/output and Imports/output are the exports and the imports in the sector divided by the total output in the sector. All specifications are estimated using OLS, and including country*time and sector fixed effects. Variable definitions and sources are described in detail in the text. 
Table 4

De facto financial liberalization and volatility, 10-year panel estimates.

\begin{tabular}{|c|c|c|c|c|c|c|}
\hline & $(1)$ & $(2)$ & $(3)$ & $(4)$ & $(5)$ & $(6)$ \\
\hline \multicolumn{7}{|c|}{ Dep. var:: standard deviation of the growth rate of output } \\
\hline \multirow[t]{2}{*}{ FINOPEN } & $0.266^{* *}$ & $0.271^{* *}$ & $0.269 *$ & $0.277^{*}$ & & \\
\hline & {$[0.108]$} & [0.109] & [0.147] & [0.149] & & \\
\hline \multirow[t]{2}{*}{ Extern. fin*FINOPEN } & & & & & $0.164^{* *}$ & \\
\hline & & & & & {$[0.081]$} & \\
\hline \multirow[t]{2}{*}{ Liq. needs $*$ FINOPEN } & & & & & & $1.836^{* * *}$ \\
\hline & & & & & & {$[0.598]$} \\
\hline \multirow{2}{*}{ Log(Output/worker) } & $-0.021^{* * *}$ & $-0.021^{* * *}$ & -0.021 & -0.023 & $-0.020 * * *$ & $-0.020 * * *$ \\
\hline & [0.005] & [0.005] & {$[0.013]$} & {$[0.014]$} & {$[0.005]$} & {$[0.005]$} \\
\hline \multirow[t]{2}{*}{ Initial share } & $-0.283^{* * *}$ & $-0.282^{* * *}$ & $-0.289 *$ & $-0.335^{* *}$ & $-0.288^{* * *}$ & $-0.280^{* * *}$ \\
\hline & {$[0.041]$} & [0.042] & {$[0.147]$} & {$[0.166]$} & {$[0.042]$} & {$[0.042]$} \\
\hline \multirow[t]{2}{*}{ Exports/output } & 0.005 & -0.018 & -0.145 & -0.211 & -0.043 & -0.039 \\
\hline & {$[0.124]$} & [0.120] & {$[0.210]$} & {$[0.211]$} & {$[0.128]$} & [0.129] \\
\hline \multirow[t]{2}{*}{ Imports/output } & -0.005 & 0.000 & 0.005 & 0.016 & 0.000 & -0.001 \\
\hline & {$[0.025]$} & {$[0.024]$} & [0.031] & [0.031] & {$[0.025]$} & {$[0.025]$} \\
\hline \multirow[t]{2}{*}{ Private credit } & 0.007 & 0.014 & -0.067 & 0.011 & & \\
\hline & [0.048] & [0.047] & {$[0.080]$} & [0.093] & & \\
\hline \multirow[t]{2}{*}{ Private credit*Liq. needs } & -0.08 & -0.128 & 0.38 & -0.1 & & $-0.330^{* *}$ \\
\hline & {$[0.160]$} & [0.155] & {$[0.410]$} & [0.525] & & {$[0.148]$} \\
\hline \multirow{2}{*}{\multicolumn{2}{|c|}{ Private credit*Extern. fin }} & & & & -0.006 & \\
\hline & & & & & {$[0.020]$} & \\
\hline Country FE & Yes & Yes & No & No & No & No \\
\hline Sector FE & Yes & No & No & No & No & No \\
\hline Time FE & Yes & No & Yes & No & No & No \\
\hline Country*sector FE & No & No & Yes & Yes & No & No \\
\hline Sector*Time FE & No & Yes & No & Yes & Yes & Yes \\
\hline Country* Time FE & No & No & No & No & Yes & Yes \\
\hline Observations & 3761 & 3761 & 3761 & 3761 & 3761 & 3761 \\
\hline$R$-squared & 0.39 & 0.41 & 0.65 & 0.66 & 0.48 & 0.48 \\
\hline
\end{tabular}

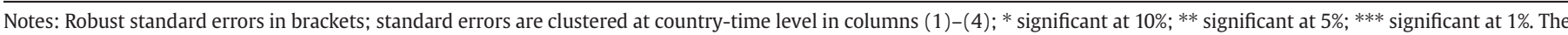



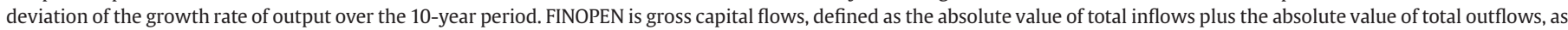

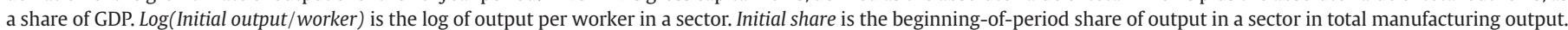



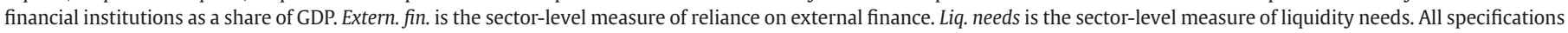
are estimated using OLS, and including the fixed effects specified in the table. Variable definitions and sources are described in detail in the text.

are not directly comparable, however. It could be, for instance, that a typical de jure episode we analyze is equivalent to a more than one standard deviation change in de facto openness.

Our difference-in-differences approach that uses the de jure indicators requires a precise dating of financial liberalization reforms. Because of this, we transform the KS measure into a binary indicator and thus overlook the gradual nature of the financial liberalization process. As a robustness check, we used the original KS index in place of FINOPEN in the panel specification model (3)). ${ }^{15}$ Table A6 in the supplementary web appendix shows that our results are robust to this alternative estimation strategy.

\subsection{Factor accumulation vs. total factor productivity growth}

We next investigate the channels through which financial liberalization increases the growth rate of output. We would like to know whether it is associated with greater entry (the number of firms). Furthermore, as in a standard growth accounting framework, growth in total production can come from increased employment, capital accumulation, and growth in total factor productivity (TFP). We use the standard techniques to construct the capital stock and a TFP series for each country and sector (see, for example, Hall and Jones, 1999). The capital stock in each year $t$ is given by $K_{i c t}=(1-\delta) K_{i c t-1}+I_{i c t}$, where $I_{i c t}$ denotes investment. We take a depreciation rate $\delta=0.08$, and adopt the standard assumption that the initial level of capital stock is equal to $I_{i c 0} / \delta$. We then follow Jorgenson and Stiroh (2000) to compute total factor productivity at the industry level. Log of TFP in

\footnotetext{
15 The original KS index varies from 1 (no liberalization in any dimension) to 3 (full
} liberalization in all dimensions). year $t$ is equal to $\ln \mathrm{TFP}_{i c t}=\ln Y_{i c t}-\left(1-\alpha_{i c}\right) \ln L_{i c t}-\alpha_{i c} \ln K_{i c t}$, where $Y_{i c t}$ is the total output, and $L_{i c t}$ is the total employment in the sector. Each sector in each country has its own labor share $\alpha_{i c}$, computed as the average of the total wage bill divided by value added. ${ }^{16}$

Table 6 investigates the impact of financial liberalization on each of these components of overall growth. We estimate Eq. (1b) with the growth rate in the number of establishments, employment, capital accumulation, and TFP as dependent variables. For each of these, we report results with both the full and PSM control groups. All of the specifications are presented only with country and group $\times$ time fixed effects, though the results are robust across the various fixed effects configurations. Columns 1 and 2 use the growth rate in the number of establishments as the dependent variable. The evidence here is mixed. While the full control group sample produces zero effect, when we select the control group with the PSM procedure, it turns out that the effect of financial liberalization on entry is strongly positive. Columns 3 and 4 show that the growth rate of sector-level employment increases significantly with financial liberalization. Columns 5 and 6 investigate the impact of financial liberalization on capital accumulation. The effect is positive and robustly significant. Finally, there does not appear to be a robust positive effect of financial liberalization on TFP. In one of the specifications it is not significant, while in the other there is a positive and marginally significant coefficient.

We estimated the impact of financial liberalization on the channels for growth in two additional ways. First, we used the Rajan-Zingales identification strategy in model (2). Second, we used the de facto

\footnotetext{
${ }^{16}$ Alternatively, we applied to all countries the labor share in sector $i$ in the U.S., or the average labor share in sector $i$ across all countries in the sample. We also used labor productivity (value added per worker) instead of TFP. The results were unchanged.
} 
Table 5

De facto financial liberalization and growth, 10-year panel estimates.

\begin{tabular}{|c|c|c|c|c|c|c|}
\hline & $(1)$ & $(2)$ & (3) & $(4)$ & (5) & $(6)$ \\
\hline \multicolumn{7}{|l|}{ Dep. var.: growth rate of output } \\
\hline \multirow[t]{2}{*}{ FINOPEN } & $0.260 * * *$ & $0.259 * * *$ & $0.282^{* * *}$ & $0.286^{* * *}$ & & \\
\hline & {$[0.066]$} & {$[0.066]$} & [0.092] & {$[0.091]$} & & \\
\hline \multirow[t]{2}{*}{ FINOPEN*Extern. fin. } & & & & & $0.187^{* * *}$ & \\
\hline & & & & & {$[0.061]$} & \\
\hline \multirow[t]{2}{*}{ FINOPEN* Liq. needs } & & & & & & 0.445 \\
\hline & & & & & & {$[0.411]$} \\
\hline \multirow[t]{2}{*}{ Log(Initial output/worker) } & $-0.015^{* * *}$ & $-0.014^{* * *}$ & $-0.036^{* * *}$ & $-0.036 * * *$ & $-0.013^{* * *}$ & $-0.013^{* * *}$ \\
\hline & {$[0.004]$} & {$[0.004]$} & {$[0.008]$} & {$[0.008]$} & {$[0.004]$} & {$[0.004]$} \\
\hline \multirow[t]{2}{*}{ Initial share } & $-0.100^{* * *}$ & $-0.098^{* * *}$ & $-0.641^{* * *}$ & $-0.738 * * *$ & $-0.100^{* * *}$ & $-0.092^{* * *}$ \\
\hline & {$[0.028]$} & {$[0.029]$} & {$[0.118]$} & {$[0.128]$} & {$[0.029]$} & [0.029] \\
\hline \multirow[t]{2}{*}{ Exports/output } & 0.001 & 0.002 & -0.142 & -0.160 & 0.020 & 0.036 \\
\hline & {$[0.140]$} & [0.137] & {$[0.258]$} & {$[0.266]$} & {$[0.124]$} & {$[0.124]$} \\
\hline \multirow[t]{2}{*}{ Imports/output } & -0.021 & -0.019 & 0.004 & 0.009 & -0.027 & -0.029 \\
\hline & {$[0.024]$} & {$[0.024]$} & [0.035] & {$[0.035]$} & {$[0.021]$} & {$[0.021]$} \\
\hline \multirow[t]{2}{*}{ Private credit } & 0.008 & 0.01 & -0.003 & -0.005 & & \\
\hline & [0.029] & [0.029] & {$[0.042]$} & {$[0.044]$} & & \\
\hline \multirow[t]{2}{*}{ Private Credit*Extern. fin } & $0.036^{* *}$ & $0.038^{* *}$ & 0.096 & 0.112 & 0.017 & \\
\hline & {$[0.017]$} & [0.017] & {$[0.062]$} & {$[0.076]$} & [0.015] & \\
\hline \multicolumn{2}{|l|}{ Private credit* Liq. needs } & & & & & $\begin{array}{l}0.078 \\
{[0.111]}\end{array}$ \\
\hline Country FE & Yes & Yes & No & No & No & No \\
\hline Sector FE & Yes & No & No & No & No & No \\
\hline Time FE & Yes & No & Yes & No & No & No \\
\hline Country* sector FE & No & No & Yes & Yes & No & No \\
\hline Sector*time FE & No & Yes & No & Yes & Yes & Yes \\
\hline Country* time FE & No & No & No & No & Yes & Yes \\
\hline Observations & 3777 & 3777 & 3777 & 3777 & 3777 & 3777 \\
\hline$R$-squared & 0.31 & 0.33 & 0.57 & 0.59 & 0.41 & 0.41 \\
\hline
\end{tabular}



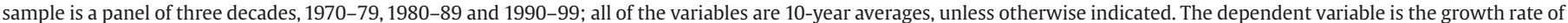

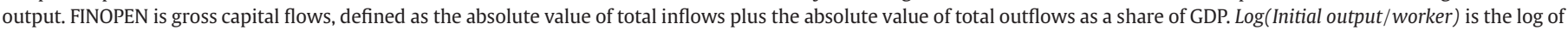

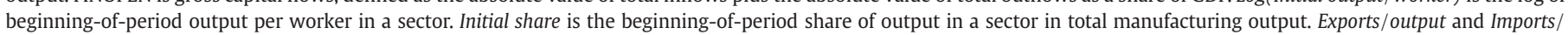



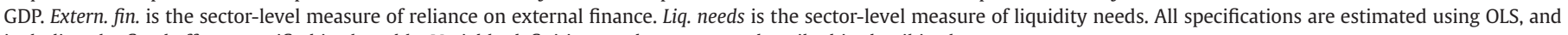
including the fixed effects specified in the table. Variable definitions and sources are described in detail in the text.

financial openness indices and estimated model (3) for each subcomponent of growth. In addition, we combined the RajanZingales strategy with de facto indices. The results are reported in Tables A7 and A8 of the supplementary web appendix to this paper. They confirm our conclusions regarding the channels for the growth impact of financial liberalization: there is a robust effect on employment and capital accumulation, and suggestive evidence of increased entry. However, by and large there is no robust impact of financial liberalization on TFP growth. ${ }^{17}$

\subsection{Temporary vs. permanent effects}

This paper uses a variety of empirical strategies to document the effect of financial liberalization on growth, volatility, and the various subcomponents of output at a 10 -year horizon. Going much beyond 10 years would be impractical, as there aren't many liberalization episodes in the sample that occurred more than 10 years before our data ends. However, we can still investigate whether the magnitude of the effect of financial liberalization changes over time. This will allow us to establish whether the impact of liberalization on various outcomes is short-lived, or has a chance to be long-lasting.

\footnotetext{
17 We do not report here the decomposition of the volatility results into channels as we did with the growth results. While in growth accounting the growth rates of each component of the production function add up to the total, the volatilities of the subcomponents do not add up to the volatility of the total because of the covariances among the subcomponents. Thus, it is not as informative to report the effect of financial liberalization on each subcomponent, and may be misleading as to what is responsible for the overall effect if the covariances are also changing. Results are nevertheless available upon request.
}

In this section, we break the post-liberalization periods into 3-year intervals: $0-2,3-5,6-8$, and 9-11 years, and use the difference-indifferences model (1) with the PSM control group to estimate the treatment effect $\left(\beta_{1}\right)$ for each 3-year period after liberalization. Examining these coefficients will tell us at which lag the effect of financial liberalization is at its strongest. Fig. 2 presents the results. It plots $\beta_{1}$ over time, along with the $90 \%$ confidence intervals.

The left panel of Fig. 2 presents the timing of the growth effects. It is clear that the positive effect of financial liberalization occurs early in the sample: the first 6 years. At longer lags, the effect of financial liberalization on growth becomes muted and not statistically significant. The time pattern also indicates that the growth effect in the post-liberalization period is highly non-stationary: growth rises on impact, accelerates further 3 to 5 years after liberalization, and then decelerates to reach zero at the end of the 12 year period. An interesting question is how much of the increase in growth volatility within 10 years found in Section 4.1 is due to the non-stationarity of the growth transition. To measure this, we compute the increase in growth volatility implied by the time evolution of the growth effects. We find that it amounts to $1.8 \%$, a figure only slightly lower than the average post-liberalization effect for volatility in the 10 year window presented in Table $1(2.22 \%)$.

The right panel of Fig. 2 presents the timing of the volatility effects. Note that we measure the impact of financial liberalization on shortrun growth volatility within each 3-year interval, abstracting from the impact of change in growth between intervals discussed above. We find that the growth volatility experiences a sharp increase in the immediate aftermath of financial liberalization. This effect is reduced over time but remains positive. In the last interval - 9-11 years - the effect on volatility is equal to $1.7 \%$, though it is not statistically different from zero ( $P$-value of 15.6\%). Therefore, we cannot 
Table 6

Difference-in-differences results based on control countries, channels.

\begin{tabular}{|c|c|c|c|c|c|c|c|c|}
\hline & $(1)$ & $(2)$ & (3) & (4) & (5) & (6) & (7) & $(8)$ \\
\hline & \multicolumn{2}{|c|}{ Number of establishments } & \multicolumn{2}{|l|}{ Employment } & \multicolumn{2}{|c|}{ Capital accumulation } & \multicolumn{2}{|c|}{ Total factor productivity } \\
\hline \multirow[t]{2}{*}{ Treated } & 0.006 & $0.028^{* * *}$ & $0.011 * *$ & $0.023 * * *$ & $0.018^{*}$ & $0.040^{* * *}$ & $0.010^{*}$ & 0.000 \\
\hline & [0.009] & {$[0.007]$} & [0.005] & {$[0.005]$} & [0.011] & {$[0.011]$} & [0.006] & [0.006] \\
\hline \multirow[t]{2}{*}{ Post } & $-0.084^{* * *}$ & $-0.018^{* * *}$ & $-0.054^{* * *}$ & $-0.050^{* * *}$ & $0.023^{* *}$ & $-0.061^{* * *}$ & -0.008 & 0.002 \\
\hline & {$[0.027]$} & {$[0.007]$} & [0.007] & [0.006] & [0.011] & [0.009] & {$[0.006]$} & [0.008] \\
\hline \multirow[t]{2}{*}{ Exports/output } & -0.003 & $0.011^{*}$ & $0.007^{*}$ & 0.004 & 0.003 & -0.002 & -0.003 & 0.000 \\
\hline & {$[0.003]$} & [0.006] & {$[0.004]$} & [0.004] & {$[0.003]$} & [0.005] & {$[0.003]$} & [0.003] \\
\hline \multirow[t]{2}{*}{ Imports/output } & 0.000 & $-0.003^{* *}$ & $-0.001^{* * *}$ & -0.003 & 0.000 & 0.002 & 0.000 & $-0.005^{* * *}$ \\
\hline & {$[0.000]$} & {$[0.001]$} & {$[0.000]$} & {$[0.002]$} & {$[0.000]$} & {$[0.002]$} & {$[0.000]$} & {$[0.001]$} \\
\hline \multirow[t]{2}{*}{ Initial share } & -0.023 & -0.044 & $-0.049 * * *$ & -0.031 & $0.048^{* * *}$ & $0.049 * * *$ & $-0.056^{* * *}$ & $-0.060^{* *}$ \\
\hline & {$[0.014]$} & {$[0.026]$} & {$[0.018]$} & [0.019] & {$[0.014]$} & {$[0.018]$} & {$[0.013]$} & {$[0.023]$} \\
\hline \multirow{2}{*}{ Private credit } & 0.124 & 0.092 & -0.019 & -0.018 & 0.033 & 0.057 & $-0.068^{* * *}$ & -0.065 \\
\hline & {$[0.078]$} & {$[0.056]$} & {$[0.015]$} & [0.033] & [0.027] & [0.068] & {$[0.017]$} & {$[0.039]$} \\
\hline \multirow[t]{2}{*}{ Private credit*Extern. fin } & $0.045^{* * *}$ & $0.049 * * *$ & $0.048^{* * *}$ & $0.055^{* * *}$ & $0.048^{* * *}$ & $0.060 * * *$ & $0.007^{* * *}$ & 0.002 \\
\hline & {$[0.005]$} & {$[0.006]$} & {$[0.004]$} & [0.005] & {$[0.004]$} & {$[0.005]$} & {$[0.002]$} & [0.003] \\
\hline Country FE & Yes & Yes & Yes & Yes & Yes & Yes & Yes & Yes \\
\hline Group*Time FE & Yes & Yes & Yes & Yes & Yes & Yes & Yes & Yes \\
\hline Control group & All & PSM & All & PSM & All & PSM & All & PSM \\
\hline Observations & 2870 & 1510 & 3839 & 1764 & 3287 & 1539 & 3267 & 1536 \\
\hline$R$-squared & 0.42 & 0.47 & 0.4 & 0.48 & 0.58 & 0.65 & 0.24 & 0.2 \\
\hline
\end{tabular}

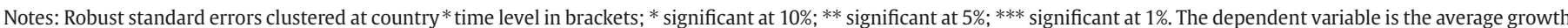

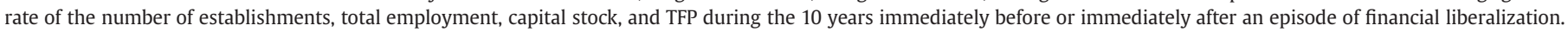

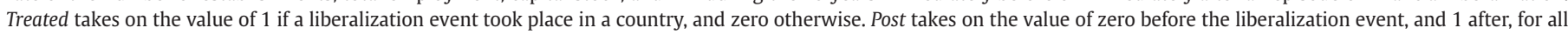

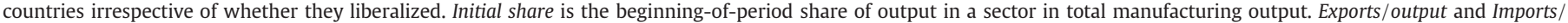

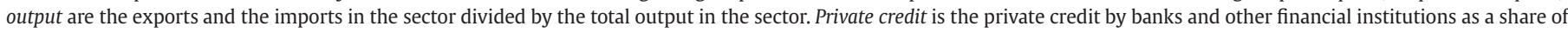

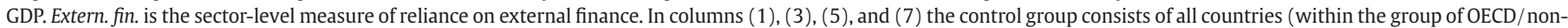

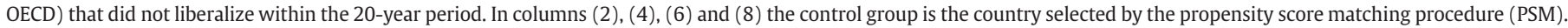
All specifications are estimated using OLS, and including the fixed effects specified in the table. Variable definitions and sources are described in detail in the text.

definitively rule out the possibility of a permanent increase in shortrun volatility on top on the temporary increase in medium-run volatility resulting from the growth transition.

How does financial liberalization affect the subcomponents of total output analyzed in this paper? Fig. 3 presents the timing of the effects for each channel affecting growth. ${ }^{18}$ Panel 1 presents the treatment effect on the growth of the number of establishments. There is a positive effect in the short-run, same as for the total output. ${ }^{19}$ Panel 2 presents the results on employment growth. These mirror the overall output results: a positive and significant short-run effect, becoming muted at longer lags. The results for capital accumulation growth are presented in Panel 3. What is interesting here is that the effect of financial liberalization is both longer-lasting, and increasing over time, until the 9th year or so after liberalization. Thus, the capital accumulation effect is more persistent than the other outcomes: since capital apparently adjusts slowly, it takes longer to attain the full impact. Unlike the output and employment effects, the effect of financial liberalization on capital accumulation is still positive at the longest lag, but it is not significant due to substantially widened error bands. Panel 4 presents the TFP chart. Consistent with the regression results from almost all of our specifications, there is no persistent effect of financial liberalization on TFP growth. It is only in the first two periods that TFP growth increases significantly. To see whether there is an effect on the level of TFP at 10 year horizon, we compound the point estimates for each subsequent three-year interval. We find a cumulative level effect on TFP close to zero.

Finally, panel 5 considers another outcome, the level of the pricecost margin. It is defined as follows:

$\mathrm{PCM}=\frac{\text { value of sales }- \text { wages }- \text { cost of inputs }}{\text { value of sales }}$

\footnotetext{
${ }^{18}$ For the reasons mentioned in footnote 17, we do not report the time evolution of the volatility of components of output. This figure is available upon request.

19 The results for the number of firms are not presented for the last period (9-11 years), as the coverage for the number of firms is more sparse than for other variables, and thus there are not enough observations to obtain a reliable last period estimate.
}

and is meant to capture the size of markups, and thus the competitiveness of the industry (see Braun and Raddatz, 2008). ${ }^{20}$ The effect of financial liberalization on the price-cost margin is negative and significant, quite pronounced, and appears persistent. We call this reduction in markups the pro-competitive effect of financial liberalization.

The finding of a reduction in the markups can, in part, explain why we find a permanent effect on the level output without any detectable effects on TFP. Since the presence of markups introduces a wedge between the marginal product of capital and the rental rate of capital, their reduction can lead to a higher steady-state level of capital and output, as shown by Galí $(1994,1995)$. Such a permanent effect on the level of output is also likely to result in much larger welfare gains from financial liberalization than the ones implied by the standard neoclassical model (Gourinchas and Jeanne, 2006).

A general feature of our results is the apparent lack of significant effects of financial liberalization on total factor productivity growth. These results should be interpreted with caution, as the construction of TFP may be subject to several measurement biases. First, we do not have direct information on the use of intermediate inputs in sectoral production. The direction of the resulting bias is hard to assess since it depends on the change in the use of intermediate inputs relative to the other factors of production. ${ }^{21}$ Second, as shown by Hall (1988), a change

\footnotetext{
20 The PCM is essentially a measure of profitability, or the flow accrued to owners of capital. Though imperfect as a measure of markups, it has the advantage of simplicity, and has been widely used in the literature. It is also highly correlated to other indicators of competitiveness, such as industry concentration ratios (see, e.g., Domowitz et al. 1986). Furthermore, note that our empirical strategy relies on the time variation in this index. Thus, to the extent that mismeasurement occurs mainly in the cross-section of countries or industries rather than differentially over time, the results are still informative.

${ }^{21}$ In particular, the fact that a large number of industrial sectors produce intermediate inputs and have experienced higher growth following liberalization possibly suggesting a higher demand for intermediates from other industries - is not directly informative of the direction of the bias in measured TFP growth. An alternative method is to derive total factor productivity growth from value added instead of output. This approach has the advantage of controlling for the role intermediate inputs but it requires separability between the value added production function and intermediate inputs, a condition generally not met in industry-level data (see Jorgenson et al., 1987). We nevertheless computed an alternative measure of TFP based on value added and the results were unchanged.
} 

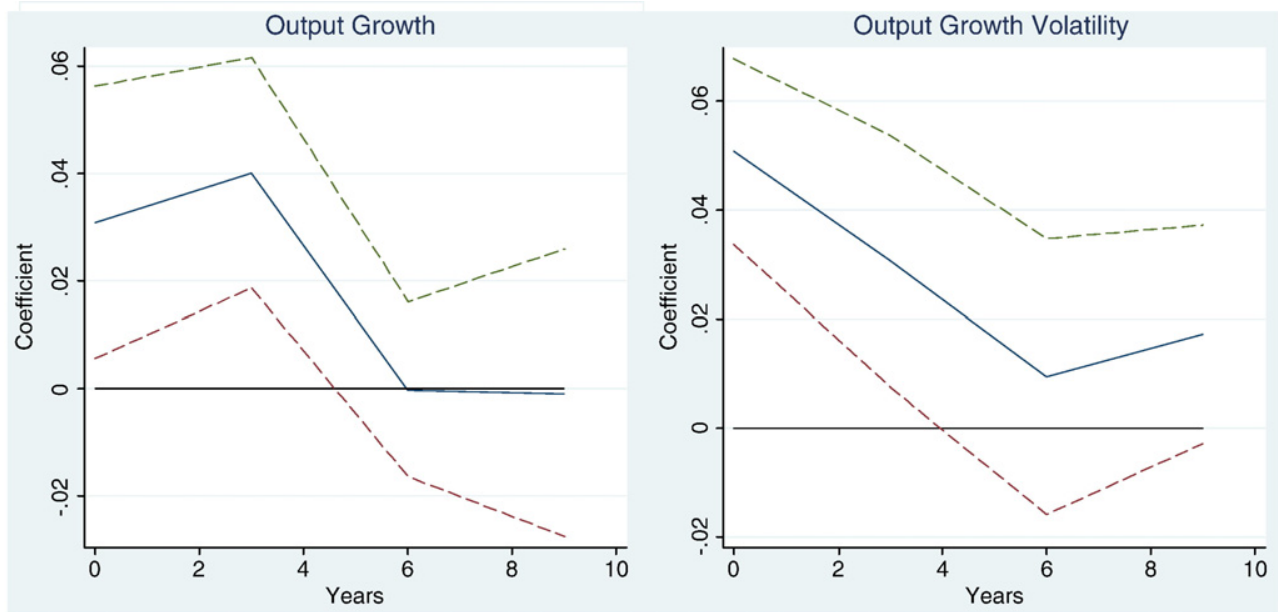

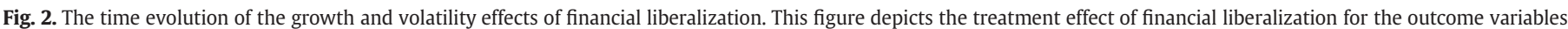

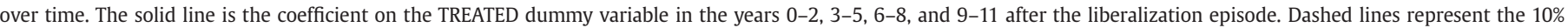
significance bands.

in the Solow residual under imperfect competition can reflect both a change in total factor productivity and a change in markups. Note that a reduction in markups - suggested by the observed reduction in the price-cost margin following liberalization - would if anything bias our results in favor of finding a positive TFP effect. ${ }^{22,23}$ Finally, beyond measurement issues, our results are consistent with the recent findings of Hale and Long (2007) on the lack of productivity spillovers on domestic firms stemming from foreign direct investment flows.

\subsection{Aggregation}

Armed with point estimates of how financial liberalization changes sector-level growth and volatility, we can now calculate what these imply for the aggregate economy. In a country comprised of sectors $i=i=1, \ldots, I$, denote the level of an aggregate variable by upper case $Y^{\mathrm{A}}$, and its growth rate by lower case $y^{\mathrm{A}}$. The aggregate growth rate can be written as:

$y^{\mathrm{A}}=\sum_{i=1}^{I} s_{i} y_{i}$

where $s_{i}$ is the share of sector $i$ in the overall level of $Y^{\mathrm{A}}$ in the country, and $y_{i}$ is the growth rate of this variable in sector $i$. This paper estimates the change in sector-level growth rate, $\Delta y$, that comes as a result of financial liberalization. The change in the aggregate growth rate could be obtained from Eq. (4) in a straightforward manner:

$\Delta y^{A}=\sum_{i=1}^{I} s_{i} \Delta y=\Delta y$

That is, if in each sector the growth rate of a variable increases by $\Delta y$, then the aggregate growth of that variable will rise by the same amount.

Note that this expression applies to all variables we analyzed: output, employment, capital stock, and TFP. To compute the change in aggregate TFP in the same way as we compute changes in output,

\footnotetext{
22 Using a fully specified model, Jaimovich (2007) shows that "true" TFP growth $(\hat{z})$ is related to the change in the markups $(\hat{\mu})$ and the Solow residual $(S R)$ as follows:

$\hat{z}=S R+\hat{\mu}$.

Since our measure of TFP is the Solow residual, a reduction in markups - negative $\hat{\mu}-$ implies that the "true" change in TFP is actually lower than our estimates, not higher. ${ }^{23}$ See Hsieh and Klenow (2007) for a comprehensive analysis of the effect of distortions on sectoral TFP in China and India.
}

employment, and capital requires two additional simplifying assumptions. First, we must assume there is a Cobb-Douglas aggregate production function $Y_{t}=A_{t} K_{t}^{\alpha} L_{t}^{1-\alpha}$. Second, we must assume a timeinvariant share of each industry in total output, total capital and total employment. This assumption rules out composition effects. In the presence of composition effects, aggregate TFP can increase purely from expansion of high-TFP sectors and contraction of low-TFP sectors, without any change in TFP at individual sector level. In order to assess the empirical relevance of this mechanism, we reestimated the baseline model while allowing financial liberalization to affect growth in high-TFP sectors differently from growth in low-TFP sectors. We found no evidence of composition effects due to financial liberalization: sectors with higher than average initial TFP do not appear to grow systematically faster than sectors with low initial TFP after liberalization (estimation results are available upon request). ${ }^{24}$

The empirical analysis above produces the point estimate $\widehat{\Delta y}$ of the change in sector-level average growth rate in the 10 years following financial liberalization. From Eq. (5) we immediately get $\Delta y^{\AA}=\widehat{\Delta y}$. By the same argument, the standard errors of the aggregate growth effects are simply equal to the standard errors of the sectoral growth estimates for each variable of interest. Panel A of Table 7 reports the estimated impact of financial liberalization on aggregate growth rates of the variables used in the analysis. Not surprisingly, they correspond to the values reported in Tables 2 and 6 above.

Next, we evaluate the long-run impact of financial liberalization. Section 4.3 establishes that there is no long-run impact on growth. However, the temporary growth impact over the first 10 years following liberalization compounds to yield a long-run level effect. Since the growth effects of liberalization do not persist after 10 years, the permanent level effect results from compounding each sectoral growth

24 The first assumption yields the level of aggregate TFP as a function of sector-level TFPs:

$\mathrm{A}_{t}=\frac{Y_{t}}{K_{t}^{\alpha} L_{t}^{1-\alpha}}=\sum_{i} \mathrm{~A}_{i t}\left(\frac{K_{i t}}{K_{t}}\right)^{\alpha}\left(\frac{L_{i t}}{L_{t}}\right)^{1-\alpha}$.

The second assumption leads to the change in the growth rate of aggregate TFP equal to:

$$
\begin{aligned}
\Delta a_{t}^{\mathrm{A}} & =\frac{d \mathrm{~A}_{t}}{\mathrm{~A}_{t}}=\sum_{i} \frac{d \mathrm{~A}_{i t}}{\mathrm{~A}_{t}}\left(\frac{K_{i t}}{K_{t}}\right)^{\alpha}\left(\frac{L_{i t}}{L_{t}}\right)^{1-\alpha} \\
& =\sum_{i} \frac{d \mathrm{~A}_{i t}}{\mathrm{~A}_{i t}} \frac{Y_{i t}}{Y_{t}}=\sum_{i} s_{i} \Delta a_{t}=\Delta a_{t},
\end{aligned}
$$

same as Eq. (5). 




Capital Stock



Price-Cost Margin

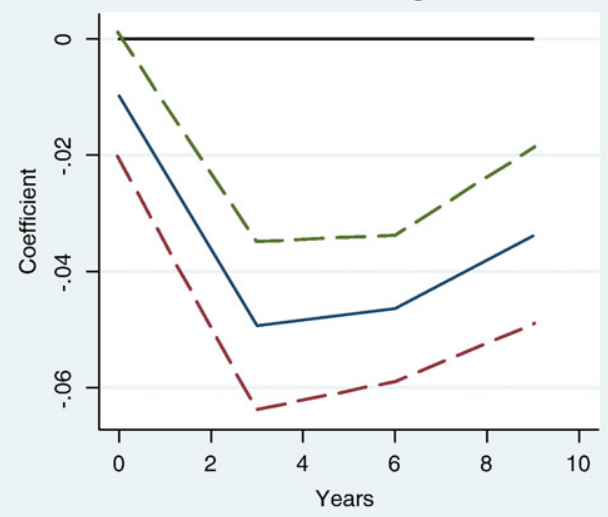



TFP

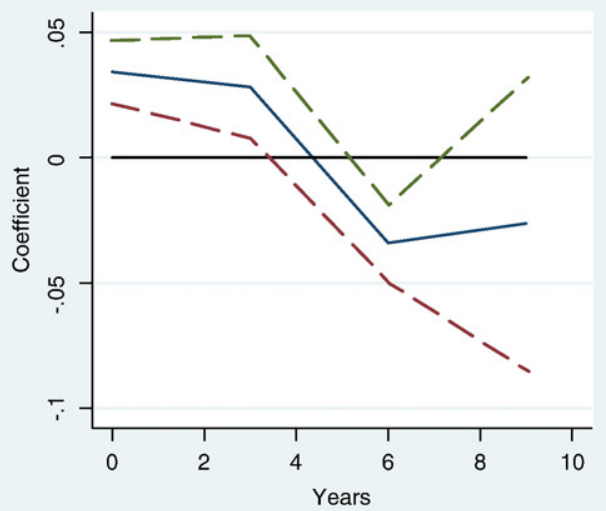

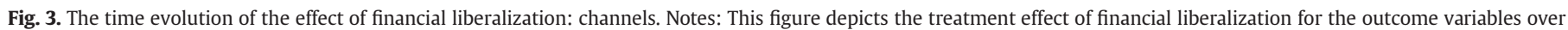

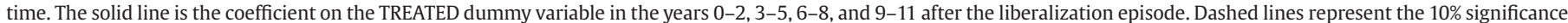
bands. All variables are in growth rates with the exception of the price-cost margin which is in level.

effect over 10 years: $1+\Delta Y_{\infty}^{A}=(1+\Delta y)^{10}$. Hence we set the estimated impact to be $\widehat{\Delta Y_{\infty}^{A}}=(1+\widehat{\Delta y})-1$. Panel $\mathrm{C}$ of Table 7 reports the results. Given the point estimates, we compute the standard errors using the delta method. ${ }^{25}$ In addition, in order to assess whether this long-run impact is statistically different from zero, the $t$-test is not sufficient due to the non-linear transformation of the regression

\footnotetext{
${ }^{25}$ Assuming $\widehat{\Delta y}$ is close enough to its true value, we use the following first order Taylor approximation:

$\widehat{\Delta Y_{\infty}^{\mathrm{A}}}-\Delta Y_{\infty}^{\mathrm{A}} \simeq 10(1+\Delta y)^{9} \cdot(\widehat{\Delta y}-\Delta y)$ Therefore, $E\left(\widehat{\Delta Y_{\infty}^{A}}\right) \simeq \Delta Y_{\infty}^{\mathrm{A}}$ and $\sqrt{\operatorname{Var}\left(\widehat{\Delta Y_{\infty}^{\mathrm{A}}}\right)} \simeq 10(1+\widehat{\Delta y})^{9} \sqrt{\widehat{\varepsilon^{2}}}$ where $\hat{\varepsilon}$ is the esti-
mated standard error of $\Delta y$.
}

estimates. Therefore, the statistical significance of the long-run level effect reported in Table 7 comes from a Wald test of this non-linear relationship. We can see that while the growth effect is confined to the first decade after liberalization, its estimated long-run level effect is still substantial. The level of aggregate output increases by $28 \%$, behind a rise of $25.5 \%$ in employment, and of $48 \%$ in the capital stock. ${ }^{26}$

\footnotetext{
${ }^{26}$ We choose to report the long-run level effect based on the estimates from the baseline 10-year regressions in Section 4.1, rather than the 3-year interval regressions in Section 4.3. This choice is dictated primarily by the substantial difficulty in computing the standard errors of the level effect estimates based on the 3-year interval regressions. The two methods produce very similar point estimates, however, that are well within the confidence interval for the level effects reported in Table 7.
} 
Table 7

The impact on aggregate growth and aggregate volatility.

\begin{tabular}{|c|c|c|c|c|c|c|c|c|c|c|}
\hline \multicolumn{7}{|c|}{ Short-run impact } & \multicolumn{4}{|c|}{ Long-run impact } \\
\hline \multicolumn{4}{|c|}{ Panel A: aggregate growth rate } & \multicolumn{3}{|c|}{ Panel B: aggregate volatility of output } & \multicolumn{4}{|c|}{ Panel C: aggregate level } \\
\hline Output & Capital & Employment & TFP & Herf-25 & Herf-50 & Herf-75 & Output & Capital & Employment & TFP \\
\hline $0.024^{* * *}$ & $0.040^{* * *}$ & $0.023^{* * *}$ & 0.000 & $0.006^{* * *}$ & $0.007^{* * *}$ & $0.009 * * *$ & $0.280^{* * *}$ & $0.477^{* * *}$ & $0.255^{* * *}$ & 0.000 \\
\hline$[0.006]$ & {$[0.011]$} & {$[0.005]$} & [0.006] & {$[0.0005]$} & [0.0005] & {$[0.0006]$} & {$[0.072]$} & {$[0.151]$} & [0.057] & {$[0.062]$} \\
\hline
\end{tabular}

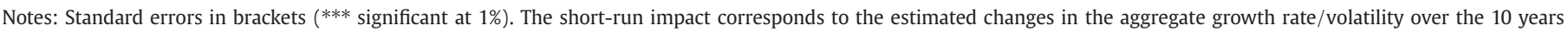

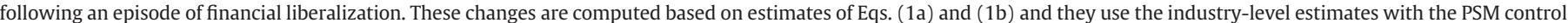

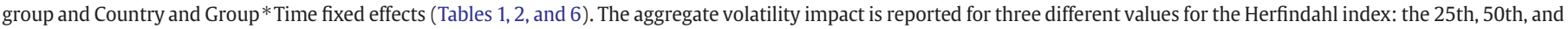


computation of point estimates and standard errors are described in detail in the text.

When it comes to volatility, Eq. (4) implies that the change in the standard deviation of aggregate output is equal to:

$\Delta \sigma^{A}=\sqrt{\sum_{i=1}^{I} s_{i}^{2} \Delta \sigma^{2}=\sqrt{h} \Delta \sigma}$,

where $\Delta \sigma$ is the impact of financial liberalization on sector-level volatility, and $h \equiv \sum_{i=1}^{I} s_{i}^{2}$ is the Herfindahl of production shares in the economy. ${ }^{27}$ In contrast to the growth increase, the change in sector-level volatility is moderated by the Herfindahl index of production shares in the economy. Thus, for any given change in sector-level volatility, the increase in aggregate volatility is much lower. For instance, the median value of $h$ in our sample is 0.087 , leading to the change in the aggregate volatility equal to about one third of the magnitude of the change in sector-level volatility: $\Delta \sigma^{\mathrm{A}}=0.29 * \Delta \sigma$. Panel $\mathrm{B}$ of Table 7 reports the change in aggregate volatility implied by the sector-level volatility estimates in this paper. While the standard deviation of volatility at sector level is predicted to rise by $2.2 \%$ in the decade following liberalization, the median economy's aggregate volatility rises by only $0.7 \%$ due to diversification across sectors. This effect is quite minor: the average standard deviation of aggregate output among the countries in our sample is 8.3\%. In contrast to the growth effect above, the volatility impact will vary depending on a country's level of diversification across sectors. To get a sense of the variation in the volatility impact across countries, Table 7 also reports the change in aggregate volatility predicted for countries in the 25th and the 75th percentiles of the diversification distribution (countries with lower Herfindahls are more diversified). We can see that the impact does not differ too much, ranging from $0.6 \%$ for the more diversified country to $0.9 \%$ for the less diversified one. The contrast between the aggregation of the growth and the volatility estimates yields an interesting conclusion. While at the sector level the growth and volatility effects appear similar in magnitude, the aggregate growth effect is on average three times larger than the aggregate volatility effect.

\section{Conclusion}

It is often argued, both theoretically and empirically, that financial liberalization should affect economic growth. At the same time, claims that financial liberalization increases volatility are made just as often. This paper uses a large panel of industry-level data to analyze both growth and volatility effects within the same empirical framework. A key strength of our approach is the number of alternative strategies we use to estimate these relationships. We employ a variety of difference-in-differences estimates, and use both de jure and de facto

\footnotetext{
27 This assumes that liberalization does not have a significant effect on the covariances between the sectors in the economy, which appears to be the case in our data.
}

measures of liberalization. We exploit sector characteristics, use nonliberalizing countries as controls, develop a propensity score matching procedure to overcome selection on observables, and use a variety of fixed effects throughout to control for omitted variables. What is remarkable is that the conclusions are virtually the same across all empirical strategies.

There is strong evidence that financial liberalization increases both growth and volatility of output. Those effects are not long-lasting: they typically vanish after 6 years. When it comes to channels, we find that financial liberalization is accompanied by an increase in the growth of employment and capital formation. Furthermore, liberalization exerts pro-competitive pressures on the product market: there is a transitory increase in the entry of firms and a permanent drop in the price to cost margin. By contrast, the growth rate of TFP does not appear to be affected by liberalization.

Thus, both growth and volatility increase as a result of financial liberalization, though admittedly the significance of the volatility results is uniformly lower. Can we say something about the net welfare impact? While a complete treatment of the welfare question would require a fully specified growth model and is therefore outside the scope of this paper, it is relatively easy to pin down the direction of the net effect. Lucas (1987) shows that the welfare benefits of removing all of the U.S. business cycle volatility are minuscule - about $0.05 \%$ of consumption. By the same logic, the adverse welfare impact of higher volatility due to liberalization is quite small. In fact, the 3 percentage point reduction in consumption volatility Lucas considered is actually higher than the 1.5-2.5 percentage point increase in output volatility implied by the estimates in this paper. Even for this small adverse effect there are several mitigating factors. First, the estimates in this paper are for the volatility of output, not consumption. If agents can self-insure by smoothing intertemporally, the implied welfare effect is lower. Second, the estimates are at sector level. Thus, if there is any amount of risk sharing across sectors, the adverse welfare impact would be reduced further. On the other hand, though the growth effect of financial liberalization is estimated to be temporary, it still translates into a permanent level effect. The results presented in this paper therefore imply that the welfare impact of financial liberalization is positive.

\section{Acknowledgments}

We are grateful to Mathieu Taschereau-Dumouchel for the superb research assistance, and to the editors, two anonymous referees, Jean Imbs, Olivier Jeanne, Raphael Lam, Gilles Saint-Paul, Aaron Tornell, Thierry Tressel, Thijs van Rens, and workshop participants at the IMF, Université de Genève, HEC-Lausanne, UCLA, PSE, INSEAD, HEC-Paris, UC Santa Cruz, IADB, ESSIM (Izmir), and CREI/CEPR Conference on Finance, Growth and The Structure of the Economy (Barcelona) for helpful comments. The views expressed in this paper are those of the authors and should not be attributed to the International Monetary Fund, its Executive Board, or its management. 


\section{Appendix A. Supplementary data}

Supplementary data associated with this article can be found, in the online version, at doi:10.1016/j.jdeveco.2008.06.003.

\section{References}

Alfaro, Laura, and Charlton, Andrew, 2007. International Financial Integration and Entrepreneurship, NBER Working Paper 13118.

Attanasio, Orazio, Davis, Steven, 1996. Relative wage movements and the distribution of consumption. Journal of Political Economy 104 (6), 1227-1262.

Banerjee, Abhijit, Duflo, Esther, 2005. Growth theory through the lens of development economics. In: Durlauf, Steven, Aghion, Philippe (Eds.), Handbook of Economic Growth, vol. 1A. Elsevier Science Ltd., North Holland.

Barro, Robert J, Mankiw, N. Gregory, Sala-i-Martin, Xavier, 1995. Capital mobility in neoclassical models of growth. American Economic Review 85, 103-115.

Beck, Thorsten, Demirgüç-Kunt, Aslí, Levine, Ross, 2000. A new database on financial development and structure. World Bank Economic Review 14, 597-605.

Bekaert, Geert, Harvey, Campbell, Lundblad, Christian, 2006. Growth Volatility and financial liberalization. Journal of International Money and Finance 25, 370-403.

Braun, Matias, Raddatz, Claudio, 2008. The politics of financial development: evidence from trade liberalization. Journal of Finance 63, 1469-1508.

Broner, Fernando, and Ventura, Jaume, 2006. Globalization and Risk Sharing, mimeo, CREI-UPF.

Dehejia, Rajeev, Wahba, Sadek, 1999. Causal effects in non-experimental studies: reevaluating the evaluation of training programs. Journal of the American Statistical Association 94, 1053-1062.

Dehejia, Rajeev, Sadek, Wahba, 2002. Propensity score matching methods for nonexperimental causal studies. Review of Economics and Statistics 84, 151-161.

di Giovanni, Julian, and Levchenko, Andrei A, in press. Trade Openness and Volatility, Review of Economics and Statistics.

Domowitz, Ian, Hubbard, R. Glenn, Petersen, Bruce, 1986. Business cycles and the relationship between concentration and price-cost margins. Rand Journal of Economics 17, 1-17.

Galí, Jordi, 1994. Monopolistic competition, endogenous markups, and growth. European Economic Review 38, 748-756.

Galí, Jordi, 1995. Product diversity, endogenous markups, and development traps. Journal of Monetary Economics 36, 39-63.

Galindo, Arturo, Micco, Alejandro, Ordoñez, Guillermo, 2002. Financial liberalization: does it pay to join the party? Economia 3, 231-252.

Glick, Reuven, Guo, Xueyan, Hutchinson, Michael, 2006. Currency crises, capital account liberalization, and selection bias. Review of Economics and Statistics 88, 698-714.

Gourinchas, Pierre-Olivier, Jeanne, Olivier, 2006. The elusive gains from international financial integration. Review of Economic Studies 73, 715-741.

Gupta, Nandini, and Yuan, Kathy, 2006. On the Growth Effects of Stock Market Liberalizations, mimeo, Indiana University and University of Michigan.

Hale, Galina, and Long, Cheryl, 2007. Is There Evidence of FDI Spillovers on Chinese Firms' Productivity and Innovation? mimeo, Federal Reserve Bank of San Francisco.

Hall, Robert E., 1988. The Relation between Price and Marginal Cost in U.S. Industry. Journal of Political Economy 96, 921-947.

Hall, Robert, Jones, Chad, 1999. Why do some countries produce so much more output per worker then others. Quarterly Journal of Economics 114, 83-116.

Hayashi, Fumio, Altonji, Joseph, Kotlikoff, Laurence, 1996. Risk-sharing between and within families. Econometrica 64 (2), 261-294.
Henry, Peter Blair, 2000a. Stock market liberalization, economic reform, and emerging market equity prices. Journal of Finance 55 (2), 529-564.

Henry, Peter Blair, 2000b. Do stock market liberalizations cause investment booms? Journal of Financial Economics 58 (1-2), 301-334.

Henry, Peter Blair, 2007. Capital account liberalization: theory, evidence, and speculation. Journal of Economic Literature 45, 887-935.

Heston, Alan, Summers, Robert, Aten, Bettina, 2002. Penn World Table Version 6.1 Center for International Comparisons at the University of Pennsylvania (CICUP).

Hsieh, Chang-Tai, and Klenow, Peter, 2007. Misallocation and Manufacturing TFP in China and India, mimeo, UC Berkeley.

Jaimovich, Nir, 2007. Firm dynamics and markup variations: implications for multiple equilibria and endogenous economic fluctuations. Journal of Economic Theory 137, 300-325.

Jorgenson, Dale W., Gollop, Frank M., Fraumeni, Barbara M., 1987. Productivity and U.S economic growth. Harvard University Press, Cambridge, MA.

Jorgenson, Dale W., Stiroh, Kevin J., 2000. U.S. economic growth at the industry level. American Economic Review 90 (2), 161-167.

Kaminsky, Graciela, Schmukler, Sergio, 2008. Short-run pain, long-run gain: the effects of financial liberalization. Review of Finance 12, 253-292.

Klingebiel, Daniela, Kroszner, Randall, Laeven, Luc, 2007. Financial crises, financial dependence, and industry growth. Journal of Financial Economics 84, 187-228.

Kose, M. Ayhan, Prasad, Eswar, Terrones, Marco, 2003. Financial integration and macroeconomic volatility. IMF Staff Papers 50, 119-142 Special Issue.

Kose, M. Ayhan, Prasad, Eswar, Rogoff, Kenneth, and Wei, Shang-Jin, 2006. Financial Globalization, A Reappraisal, IMF Working Paper 06/189.

Lane, Philip, and Milesi-Ferretti, Gian Maria, 2006. The External Wealth of Nations Mark II: Revised and Extended Estimates of Foreign Assets and Liabilities, 1970-2004, IMF Working Paper, 06/69.

Levchenko, Andrei A., 2005. Financial liberalization and consumption volatility in developing countries. IMF Staff Papers 52 (2), 237-259.

Lucas Jr., Robert E., 1987. Models of Business Cycles. Basil Blackwell, New York.

Mitton, Todd, 2006. Stock market liberalization and operating performance at the firm level. Journal of Financial Economics 81 (3), 625-647.

Obstfeld, Maurice, 1994. Risk-taking, global diversification, and growth. American Economic Review 84 (5), 1310-1329.

Persson, Torsten, 2001. Currency unions and trade: how large is the treatment effect? Economic Policy 435-448 (October).

Quadrini, Vincenzo, 2005. Policy commitment and the welfare gains from capital market liberalization. European Economic Review 49 (8), 1927-1951.

Raddatz, Claudio, 2006. Liquidity needs and vulnerability to financial underdevelopment. Journal of Financial Economics 80, 677-722.

Rajan, Raghuram, Zingales, Luigi, 1998. Financial dependence and growth. American Economic Review 88 (3), 559-586.

Saint-Paul, Gilles, 1992. Technological choice, financial markets and economic development. European Economic Review 36, 763-781.

Smith, Jeffrey, Todd, Petra, 2005. Does matching overcome LaLonde's critique of nonexperimental estimators? Journal of Econometrics 125 (1-2), 305-353.

Tornell, Aaron, Velasco, Andres, 1992. The tragedy of the commons and economic growth, why does capital flow from poor to rich countries? Journal of Political Economy 100, 1208-1231.

Tressel, Thierry, and Verdier, Thierry, 2007. Does Financial Globalization Discipline Politically Connected Firms, mimeo, IMF.

United Nations Industrial Development Organization, 2006. Industrial Statistics Database, CD-ROM. 